\title{
PENCABUTAN HAK ATAS TANAH DAN BENDA YANG ADA DIATASNYA: ANTARA ADA DAN TIADA
}

\author{
(Revocation of Interest in Land and Property: A Grey Area)
}

\author{
Rofi Wahanisa \\ Fakultas Hukum Universitas Negeri Semarang (UNNES), \\ Gd. K Lantai 1 Fakultas Hukum UNNES Kampus Sekaran Gunungpati Kota Semarang \\ email: rofiwahanisa@mail.unnes.ac.id ; rofiwahanisa@yahoo.com
}

Naskah diterima: 25 Agustus 2019; revisi: 18 Oktober 2019; disetujui: 8 November 2019

\begin{abstract}
Abstrak
Perubahan adalah suatu keniscayaan sebagai cara untuk mengikuti perkembangan jaman, bisa terjadi di segala sisi kehidupan. Perubahan bisa dilakukan secara cepat maupun secara pelan atau bertahap. Perubahan tersebut sering disebut dengan reformasi. Pun dalam bidang hukum, perlu dilalukan reformasi, baik secara cepat maupun bertahap, dalam hal pembentukan dan penegakan hukum. Salah satu bentuk reformasi yang dilakukan secara bertahap di bidang hukum adalah dengan melakukan perubahan undang-undang. Termasuk di bidang pertanahan dengan melakukan identifikasi peraturan yang secara eksistensinya antara "ada dan tiada". Salah satu peraturan yang secara eksistensi ada namun keberlakuannya hanya sekali diberlakukan yaitu di bidang pengadaan tanah yaitu Undang-undang Nomor 20 Tahun 1961 tentang Pencabutan Hak-Hak atas Tanah dan Benda-benda yang ada diatasnya. Dalam tulisan ini akan dibahas lebih lanjut mengenai keberadaan Undang-undang Nomor 20 Tahun 1961 tentang Pencabutan Hak-Hak atas Tanah dan Benda-benda yang ada diatasnya, hal ini menjadi penting untuk dibahas dengan semakin massive nya kegiatan pembangunan khususnya di bidang infrastruktur. Hal ini tentu, selain memerlukan peraturan yang akamodatif sebagai payung hukum pelaksanaan kegiatan pengadaan tanah, untuk mewujudkan kepentingan umum sekaligus diperlukan aturan hukum yang memberikan kepastian, sekaligus kemanfaatan dan keadilan bagi semua pihak yang terlibat dalam pelaksanaan kegiatan pengadaan tanah.
\end{abstract}

Kata Kunci: pencabutan hak atas tanah, pengadaan tanah, kepentingan umum

\begin{abstract}
Change is a necessity as a way to keep up with the times, can occur in all aspects of life. Changes can be done quickly or slowly or gradually. These changes are often called reforms. Even in the field of law, reforms need to be carried out, both quickly and gradually, in terms of the formation and enforcement of the law. One form of reform that is carried out in stages in the legal field is by making changes to the law. Reform in land affairs needs to be undertaken in order to identify regulations which are existentially in a grey area. One of the regulations which exists but was only applied once in land affairs is the Law No. 20/1961 on Revocation of Land and the Things above. This paper further discusses the existence of the Law No. 20/1961 on Revocation of Land Right and the Things above. This issue becomes crucial to discuss regarding massive development activities, particularly in infrastructure sector. This obviously needs not only accommodative regulations as the legal protection of land acquisition activities to realize public interest but also legal regulations which give certainty, benefits, and justice for all parties involved in the activities of land acquisition.
\end{abstract}

Keywords: revocation of land right, land acquisition, public interest 


\section{A. Pendahuluan}

Reformasi pertanahan adalah suatu hal yang niscaya untuk dilakukan, termasuk dalam lingkup peraturan perundang-undangan. Hal ini diperlukan untuk mengurai keadaan tumpang tindih regulasi yang terjadi dalam peraturan perundangan. Tumpang tindih regulasi diartikan adanya ketidaksinkronan antara peraturan yang lebih tinggi kedudukannya dengan peraturan yang lebih rendah kedudukannya. Ketidaksinkronan regulasi, selain dipergunakan istilah tumpang tindih regulasi juga dipergunakan istilah hiper, over dan obesitas regulasi. Yang dimaksudkan dengan hiper dalam dalam Kamus Besar bahasa Indonesia (KBBI) diartikan "berlebihan"; "di luar atau terlampau melampaui batas". Sedangkan, Obesitas dalam KBBI mempunyai arti "penumpukan lemak yang berlebihan di dalam badan; kegemukan yang berlebih". $\mathrm{Hal}$ ini berkaitan dengan kondisi badan dan kesehatan seseorang, dan dipergunakan untuk menggambarkan kondisi kesehatan. Namun, ketiga kata tersebut, hiper, over dan obesitas merujuk makna yang sama yaitu berlebihan, dan melampaui batas.

Upaya untuk melakukan reformasi pertanahan, hal awal yang dapat dilakukan adalah melakukan inventarisasi. Kegiatan inventarisasi penting dilakukan untuk melihat keberadaan peraturan perundang-undangan yang masih berlaku dan yang sudah tidak lagi berlaku. Dengan demikian dapat dilihat peraturan-peraturan manakah yang masih efektif untuk berlaku, dan manakah peraturan yang secara keberadaannya ada, namun pemberlakuannya tidak efektif, atau bahkan belum pernah diberlakukan sama sekali.
Dalam tulisan ini akan membahas mengenai peraturan di bidang pertanahan khususnya dalam lingkup pengadaan tanah, yaitu Undang-undang Nomor 20 Tahun 1961 tentang Pencabutan Hak-Hak atas Tanah dan Benda-benda yang ada diatasnya. Perkembangan ekonomi, dengan dampak globalisasinya memerlukan respon yang cepat dari segala bentuk. Kemajuan teknologi dan ekonomi juga harus ditunjang dengan perangkat hukum yang memadai sebagai payung yang dapat memberikan kepastian hukum sekaligus dapat memberikan kemanfaatan dan keadilan bagi seluruh rakyat Indonesia.

Negara sebagai organisasi kekuasaan yang diberikan wewenang dan kuasa mempunyai tugas untuk mensejahterakan rakyat sebagaimana yang "perintah" dalam konstitusi yaitu dalam Pembukaan UUD 1945 alenia ke-4, yaitu "melindungi segenap Bangsa Indonesia, dan seluruh tumpah darah Indonesia dan untuk memajukan kesejahteraan umum, mencerdaskan kehidupan bangsa, dan ikut melaksanakan ketertiban dunia yang berdasarkan kemerdekaan, perdamaian abadi dan keadilan sosial...", dan kemudian "perintah" konstitusi tersebut di derivasikan dalam Pasal 33 ayat (3) UUD 1945 yang menyatakan, "Bumi, Air dan kekayaan alam yang terkandung di bawahnya dikuasai oleh negara dan dipergunakan untuk sebesarbesar kemakmuran rakyat". ${ }^{1}$

Upaya negara untuk mewujudkan kesejahteraan rakyat tersebut dilakukan dengan pembangunan. Salah satunya yaitu dengan melakukan pembangunan infrastruktur. Pembangunan infrastruktur 
untuk memenuhi kebutuhan fasilitas umum tersebut tentu memerlukan ketersediaan tanah dalam jumlah yang cukup luas. Arah kebijakan umum pembangunan nasional 20152019 adalah mempercepat pembangunan infrastruktur untuk pertumbuhan dan pemerataan. Demi kepentingan umum, pemerintah mempunyai kewenangan konstitusional untuk memperoleh tanah dari yang punya tanah. Berdasarkan hak menguasai negara sebagaimana ditegaskan dalam Pasal 33 ayat (3) UUD 1945, pemerintah dapat melakukan perolehan tanah. ${ }^{2}$

Pengadaan tanah, sebagai proses pengambilalihan tanah dari warga negara oleh negara adalah bagian dari hak menguasai negara sebagaimana diatur dalam Pasal 2 ayat (2) Undang-Undang Nomor 5 Tahun 1960 tentang Peraturan Dasar Pokok-Pokok Agraria (UUPA), yang meliputi kewenangan:

a. mengatur dan menyelenggarakan peruntukan, penggunaan, persediaan, dan pemeliharaan bumi, air, dan ruang angkasa Indonesia.

b. Menentukan dan mengatur hubunganhubungan hukum antara orang-orang dengan bumi, air, dan ruang angkasa tersebut, dan

c. Menentukan dan mengatur hubunganhubungan hukum antara orang-orang dan perbuatan-perbuatan hukum yang mengenai bumi, air, dan ruang angkasa tersebut.

Wewenang yang muncul pada negara sebagai perwujudan dari hak menguasai Negaratersebut, adalah dengan maksudbahwa negara diberikan wewenang dan sekaligus tanggung jawab, yang dapat memberikan manfaat sebesar mungkin kemakmuran rakyat. ${ }^{3}$ Sehingga secara ideal pengadaan tanah untuk kepentingan umum pun, dalam tujuan untuk mewujudkan kesejahteraan. Oleh karena itu pengadaan tanah harus memegang prinsip keadilan, dan penghormatan terhadap hak-hak individu/ dengan diberikannya ganti kerugian. Namun demikian, dalam kenyataannya penyelenggaraan pengadaan tanah tidak berjalan mulus. Telah beberapa kali regulasi yang mengatur tentang hal ini dibuat, dan beberapa kali mengali perubahan juga pergantian, akan tetapi permasalahan yang terkait dengan pengadaan tanah tetap muncul. Problematika yang sering muncul dalam kegiatan pengadaan tanah, jika menggunakan pembagian sebagaimana pendapat Lawrance Friedman, yaitu substansi hukum, struktur hukum dan kultur hukum, maka problematika dalam pengadaan tanah memenuhi ketiga hal tersebut.

Secara substansi hukum, yaitu di bidang pengaturan pengadaan tanah, adanya permasalahan yang bersifat semantik (penafsiran), yaitu tentang penafsiran makna "kepentingan umum" yang sangat beragam dan multi tafsir, hal ini sering menjadi hal mendasar yang memunculkan sengketa/ konflik, karena tidak samanya persepsi mengenai konsepsi kepentingan umum. Karena hal yang dianggap sebagai kepentingan umum menurut negara/ pemerintah, belum tentu dianggap sebagai kepentingan umum oleh masyarakat, jika dilihat dari kemanfaatan dan keberdayagunaannya. Kemudian, hal

2 Oloan Sitorus, Dayat Limbong, Pengadaan Tanah Untuk Kepentintingan Umum, (Yogyakarta: Penerbit Mitra Kebijakan Tanah Indonesia, 2004), hlm. 1.

$3 \quad$ Pasal 33 ayat (3) UUD 1945. 
substansi lainnya, yaitu regulasi yang mengatur soal pengadaan tanah ini. Sejak masa ke masa, dimulai orde lama, orde baru sampai dengan reformasi selalu mengalami perubahan.

Era orde lama, pengambilalihan tanah oleh negara ini, dipergunakan perangkat hukum berupa pencabutan hak atas tanah, yang diatur dalam Undang-undang Nomor 20 Tahun 1961 tentang Pencabutan Hak-Hak atas Tanah dan Benda-benda yang ada diatasnya. Dipergunakannya cara pencabutan ini sebagai "amanat" dalam Pasal 18 UUPA. Namun, cara pencabutan hak atas tanah tidak serta merta dilakukan oleh negara/ pemerintah ketika ingin menggunakan hak atas tanah milik individu untuk pembangunan fasilitas/ kepentingan umum, akan tetapi mengikuti cara dan prosedur yang telah diatur, yaitu dilakukan musyawarah terlebih dahulu, jika dan pada titik tertentu tidak tercapai kata sepakat. Maka, dilakukan dengan pencabutan hak atas tanah. Dan tentu saja pemegang hak yang tanahnya dicabut diberikan ganti rugi.

Pada masa orde baru, terjadi perdebatan mengenai pengaturan tentang pengambilalihan tanah ini, perdebatan tersebut dikarenakan pengaturan mengenai pengadaan tanah/ pengambilalihan tanah ini diatur dalam bentuk Peraturan Menteri Dalam Negeri (Permendagri) Nomor 15 tahun 1975, yang dikenal dengan istilah pembebasan tanah. Permendagri ini banyak mendapatkan kritikan karena hal yang sangat berdekatan dengan hak asasi manusia seharusnya tidak cukup diatur dalam bentuk Peraturan Presiden apalagi Peraturan Menteri, namun seharusnya dalam bentuk undang-undang. Dengan adanya kritikan tersebut kemudian pengaturan diubah kembali namun juga dalam bentuk Keputusan Presiden, yaitu Keputusan Presiden (Keppres) Nomor 55 tahun 1993 tentang Pengadaan Tanah Bagi Pembangunan Untuk Kepentingan Umum. Kemudian, di masa reformasi peraturan mengenai pengadaan tanah mengalami perubahan kembali dengan dikeluarkannya Peraturan Presiden (Perpres) Nomor 36 Tahun 2005 sebagai perubahan dari Keppres Nomor 55 Tahun 1993, namun kemudian Perpres ini pun kemudian diubah kembali dengan Perpres Nomor 65 Tahun 2006. Perubahan bentuk pengaturan dari Keppres menjadi Perpres juga tetap mendapatkan kritikan.

Baru kemudian di tahun 2012, pengaturan tentang pengadaan tanah bagi pembangunan untuk kepentingan umum ini diatur dalam bentuk undang-undang. Bentuk pengaturan dengan undang-undang inilah yang sebenarnya diharapkan sedari awal. Dari berbagai perubahan dalam peraturan yang mengatur tentang pengadaan tanah dari yang berupa Permendagri, Keppres, sampai dengan Perpres kesemuanya dalam cara penyelesaian sengketa/ konflik yang terjadi pada akhirnya mempergunakan cara pencabutan hak atas tanah sebagaimana diatur dalam UndangUndang Nomor 20 Tahun 1961 sebagai upaya akhir untuk penyelesaian sengketa/ konflik atau sebagai upaya paling akhir yang dilakukan ketika tidak terjadi kesepakatan setelah dilakukan musyawarah antara instansi yang membutuhkan tanah dengan pemegang hak atas tanah. Namun, dalam Undang-Undang Nomor 2 tahun 2012 tentang Pengadaan Tanah Bagi Pembangunan Untuk Kepentingan Umum, yang dijadikan jalan akhir untuk penyelesaian sengketa/ konflik jika tidak terjadi kesepakatan antara para pihak meski telah dilakukan musyawarah adalah dengan 
konsinyasi (Penitipan Ganti Rugi di Pengadilan Negeri). Dalam UU No. 2 Tahun 2012 tidak lagi mengatur cara penyelesaian sengketa/ konflik pengadaan tanah yang terakhir (jalan akhir) setelah dilakukan musyawarah diantara para pihak (instansi yang memerlukan tanah dengan pemegang hak atas tanah) dengan mempergunakan prosedur pencabutan hak atas tanah sebagaimana diatur dalam Undang-Undang Nomor 20 Tahun 1961.

Berdasarkan uraian latar belakang tersebut diatas, maka rumusan permasalahan yang diangkat dalam tulisan ini adalah bagaimanakah kedudukan Undang-Undang Nomor 20 Tahun 1961 tentang Pencabutan Hak Atas Tanah dan Benda Diatasnya Pasca Undang-Undang Nomor 2 Tahun 2012 tentang Pengadaan Tanah Bagi Pembangunan Untuk Kepentingan Umum? Dan adakah kemungkinan digunakannya kembali Pencabutan Hak Atas Tanah sebagai tata cara memperoleh tanah bagi pembangunan untuk kepentingan umum?

\section{B. Metode Penelitian}

Menurut Soerjono Soekanto, penelitian merupakan suatu kegiatan ilmiah yang didasarkan pada metode, sistematika dan pemikiran tertentu yang bertujuan untuk mempelajari satu atau beberapa gejala hukum tertentu, dengan jalan menganalisanya. ${ }^{4}$ Dalam penelitian hukum, hukum dapat dikaji melalui 2 perspektif, yaitu ilmu hukum sebagai ajaran, norma yang mengandung nilai-nilai (values). Dan ilmu hukum yang dapat dikaji sebagai realitas. Karena hukum tidak berada di ruang hampa.

Dalam penelitian hukum dapat dilakukan dengan pendekatan yuridis normatif dan metode pendekatan yuridis sosiologis. Pendekatan yuridis normatif yang pada pencarian jawaban terhadap permasalahan dan tujuan penelitian berdasarkan kerangka teori hukum normatif, yang dipergunakan untuk menelaah data adalah teori-teori yang lazim dikenal dalam teori hukum doktrinal, seperti kaidah-kaidah hukum, asas-asas hukum, pengertian-pengertian hukum dan sebagainya. $^{5}$

Sedangkan, pendekatan yuridis sosiologis yang bercirikan pada pencarian jawaban terhadap permasalahan dan tujuan penelitian dengan menggunakan teori hukum empiris-sosiologi hukum. ${ }^{6}$ Dalam tulisan ini dipergunakan metode kualitatif yaitu, tidak hanya mengkonsepsikan hukum sebagai ajaran, norma yang mengandung nilai-nilai (values) tetapi juga melihat ilmu hukum yang mengkonsepsikan hukum sebagai realitas. ${ }^{7}$ Pendekatan penelitian yang dilakukan dalam tulisan ini adalah penelitian normatif, dengan pendekatan perundang-undangan dan pendekatan konsep, yang mengkaji studi dokumen, yakni menggunakan berbagai data sekunder seperti peraturan perundangundangan, keputusan pengadilan dan teori hukum.

Pengumpulan data dilakukan dengan pengumpulan bahan primer, sekunder,

\section{Soerjono Soekanto, Penelitian Hukum Normatif, Jakarta: RajaGrafindo Persada, 2009.}

Arief Hidayat, Kebebasan Berserikat Di Indonesia (Suatu Analisis Pengaruh Perubahan Sistem Politik Terhadap Penafsiran Hukum), (Semarang: Badan Penerbit Universitas Diponegoro, 2006), hlm. 52.

Ibid.

7 Robert Bongdan dan Teven J. Taylor, Kualitatif, Dasar-dasar Penelitian, Terjemahan A. Khozin Afandi, (Surabaya: Usaha Nasional, 1993), hlm. 30 
maupun tertier. ${ }^{8}$ Analisis data akan dilakukan secara yuridis kualitatif atau secara mendalam, komprehensif atau holistik untuk memperoleh kesimpulan terhadap permasalahan yang diteliti. Teknik analisis data yang dipergunakan dalam tulisan ini adalah teknik analisis interaktif dari Mattew B. Miles dan A. Michael Huberman. Analisis data terdiri atas tiga sub-proses yang saling terkait, yaitu reduksi data, penyajian data, dan pengambilan kesimpulan/verifikasi. ${ }^{9}$

\section{Pembahasan}

\section{Kedudukan Undang-undang Nomor} 20 Tahun 1961 tentang Pencabutan Hak-Hak atas Tanah dan Bendabenda yang ada diatasnya Pasca Undang-Undang Nomor 2 Tahun 2012 tentang Pengadaan Tanah Bagi Pembangunan Untuk Kepentingan Umum

Undang-undang Nomor 20 Tahun 1961 tentang Pencabutan Hak-Hak atas Tanah dan Benda-benda yang ada diatasnya baru sekali pernah diterapkan saat mencabut hak atas tanah atas daerah Kecamatan Taman sari yang terkenal dengan kompleks "Yen Pin" di Jakarta sebagaimana ditetapkan dalam Keppres tanggal 6 Januari 1920 Nomor 2 Tahun 1970 tentang Pencabutan Hak Atas Tanah dan benda-benda yang ada diatasnya. ${ }^{10}$
Dan Keppres ini mungkin adalah satu-satu nya Keppres tentang Pencabutan Hak Atas Tanah menurut Undang-Undang Nomor 20 Tahun 1961. ${ }^{11}$ Sebagai peraturan pelaksana UndangUndang Nomor 20 Tahun 1961 tersebut diterbitkan Instruksi Presiden Republik Indonesia Nomor 9 Tahun 1973 pada tanggal 17 November 1973.

Perkembangan selanjutnya Undangundang Nomor 20 Tahun 1961 tentang Pencabutan Hak-Hak atas Tanah dan Bendabenda yang ada diatasnya keberadaanya antara "ada dan tiada" karena Undang-Undang Nomor 20 Tahun 1961 yang selama ini dalam peraturan perundangan tentang pengadaan tanah selalu dimasukkan sebagai upaya akhir dalam penyelesaian sengketa/ konflik pengadaan tanah. Terdapat pendapat yang menyatakan bahwa, dengan diundangkannya Undang-Undang Nomor 2 Tahun 2012, maka peraturan perundang-undangan yang terkait dengan pengadaan tanah dianggap tidak lagi berlaku. Pada dasarnya, keberlakuan suatu undang-undang berlandaskan pada asasasas agar undang-undang tersebut dapat mencapai tujuannya dengan efektif. Asas-asas yang dimaksudkan adalah ${ }^{12}$ :

a. Undang-undang tersebut tidak berlaku surut, artinya bahwa undang-undang tersebut hanya boleh diterapkan terhadap peristiwa yang disebut di dalam undang-

\footnotetext{
Soerjono Soekanto dan Sri Mamudji, Penelitian Hukum Normatif: Suatu Tinjauan Singkat, Ed.1, Cet.3, (Jakarta: Rajawali, 1990), hlm. 14-15.

9 Miles, L. Mattew B. dan A. Michael Huberman, Analisis Data Kualitatif, UI Press, Jakarta, 1992, hlm. 87.

10 AP. Parlindungan, Pencabutan dan Pembebasan Hak Atas Tanah Suatu Studi Perbandingan, Cet. I, (Bandung: Mandar maju, 1993), hlm. 32

11 Abdurahman, Setengah Abad Pengaturan Tentang "Pengambilan Tanah Rakyat dari Pencabutan Hak sampai kepada Pembebasan Tanah Dalam Pengadaan Tanah bagi pembangunan Untuk Kepentingan Umum dalam Perkembangan Hukum di Indonesia, dalam Rangka 70 Tahun Prof. Dr. Mieke Komar, SH., M.CL, Bandung: PT. Remaja Rosdakarya.

12 Soehino, Hukum Tata Negara Tekhnik (Setelah Dilakukan Perubahan Pertama dan Kedua Undang-undang Dasar Negara Republik Indonesia Tahun 1945), Edisi Pertama, Yogyakarta: BPFE Fakultas Ekonomi UGM, 2006, hlm. 15
} 
undang tersebut, serta terjadi setelah undang-undang itu dianggap berlaku.

b. Undang-undang yang dibuat oleh penguasa yang lebih tinggi mempunyai kedudukan yang lebih tinggi pula.

c. Undang-undang yang bersifat khusus menyampingkan undang-undang yang bersifat umum, apabila pembuatnya sama. Artinya terhadap peristiwa khusus wajib diperlakukan undang-undang yang menyebutkan peristiwa itu, walaupun peristiwa khusus tersebut dapat pula diperlakukan undang-undang yang menyebutkan peristiwa yang lebih luas ataupun lebih umum, yang dapat mencakup peristiwa khusus tersebut.

d. Undang-undang yang berlaku belakangan, membatalkan undang-undang yang berlaku terdahulu. Artinya undang-undang lain yang lebih dahulu berlaku dimana diatur mengenai suatu hal tertentu, tidak berlaku lagi apabila ada undangundang baru yang berlaku belakangan yang mengatur pula hal tersebut, akan tetapi makna atau tujuannya berlainan atau berlawanan dengan undang-undang tersebut.

e. Undang-undang tidak dapat diganggu gugat.

f. Undang-undang merupakan suatu sarana untuk mencapai kesejahteraan spiritual dan material bagi masyarakat maupun pribadi, melalui pelestarian ataupun pembaruan (inovasi). Artinya supaya pembuat undang-undang tidak sewenangwenang atau supaya undang-undang tersebut tidak menjadi huruf mati, maka perlu dipenuhi beberapa syarat tertentu antara lain:
1) Keterbukaan di dalam proses pembuatan Undang-undang

2) Pemberian hak kepada warga masyarakat untuk mengajukan usul-usul tertentu, melalui cara-cara:

a) Penguasa setempat mengundang mereka yang berminat untuk menghadiri suatu pembicaraan mengenai peraturan tertentu yang akan dibuat.

b) Suatu departemen tertentu, mengundang organisasi-organisasi tertentu untuk memberikan masukan bagi suatu rancangan undang-undang yang sedang disusun.

c) Acara dengar pendapat di Dewan Perwakilan Rakyat.

d) Pembentukan kelompok-kelompok penasihat yang terdiri dari tokohtokoh atau ahli-ahli terkemuka

Berdasarkan asas-asas keberlakuan suatu undang-undang diatas, maka jika kita membaca ketentuan dalam "mengingat" Undang-Undang Nomor 2 Tahun 2012 yaitu:

1) Pasal 5 ayat (1), Pasal $18 \mathrm{~B}$ ayat (2), Pasal 20 , Pasal $28 \mathrm{G}$ ayat (1), Pasal $28 \mathrm{H}$, Pasal $28 \mathrm{I}$ ayat (5), Pasal $28 \mathrm{~J}$ ayat (2), serta Pasal 33 ayat (3) dan ayat (4) Undang-undang Dasar Negara Republik Indonesia 1945;

2) Undang-undang Nomor 5 Tahun 1960 tentang Peraturan Dasar Pokok-pokok Agraria (Lembaran Negara Republik Indonesia Tahun 1960 No. 104, Tambahan Lembaran Negara Republik Indonesia No. 2034)

Dari ketentuan "mengingat" dalam Undang-Undang No. 2 Tahun 2012 tersebut diatas kita dapat mengetahui bahwa dasar 
dikeluarkannya Undang-Undang Nomor 2 tahun 2012 adalah berdasarkan ketentuan sebagaimana diatur dalam Undang-Undang Nomor 5 Tahun 1960 tentang Peraturan Dasar Pokok-pokok Agraria. Selanjutnya, jika kita mencari dalam ketentuan UUPA, untuk melihat pasal manakah dalam UUPA yang mengatur/ "memerintahkan" pembentuk undang-undang untuk mengatur suatu hal dengan undang-undang yang berkaitan dengan kepentingan umum, maka jawabannya adalah dapat diketemukan dalam Pasal 18 UUPA, yang menyatakan bahwa, "untuk kepentingan umum, termasuk kepentingan bangsa dan negara serta kepentingan bersama dari rakyat, hak-hak atas tanah dapat dicabut, dengan memberi ganti kerugian yang layak dan diatur dengan undang-undang". ${ }^{13}$

Berdasarkan "perintah" dari Pasal 18 UUPA tersebut, maka dikeluarkanlah Undangundang Nomor 20 Tahun 1961 tentang Pencabutan Hak-Hak atas Tanah dan Bendabenda yang ada diatasnya. Kemudian, yang menjadi pertanyaan berikutnya apakah dengan dikeluarkannya Undang-Undang Nomor 2 tahun 2012 tentang Pengadaan Tanah Bagi Pembangunan Untuk Kepentingan Umum ini dengan sendirinya atau secara otomatis menyebabkan tidak lagi berlakunya Undang-undang Nomor 20 Tahun 1961 tentang Pencabutan Hak-Hak atas Tanah dan Benda-benda yang ada diatasnya?. Jika melihat dari asas berlakunya Undang-undang menurut pendapat Soehino tersebut diatas, dinyatakan bahwa: "undang-undang yang berlaku belakangan, membatalkan undangundang yang berlaku terdahulu. Artinya undang-undang lain yang lebih dahulu berlaku dimana diatur mengenai suatu hal tertentu, tidak berlaku lagi apabila ada undangundang baru yang berlaku belakangan yang mengatur pula hal tertentu tersebut, akan tetapi makna atau tujuannya berlainan atau berlawanan dengan undang-undang tersebut. $^{14}$

Membaca penjelasan dari asas undangundang tersebut diatas, “...tidak berlaku lagi apabila ada undang-undang baru yang

13 Menurut Purbacaraka dan Soerjono Soekanto yang dimaksudkan dengan undang-undang adalah peraturan tertulis yang berlaku umum dan dibuat oleh penguasa pusat maupun daerah yang sah. Menurut Soerjono Soekanto yang disebut undang-undang secara materiil mencakup: 1) Peraturan pusat yang berlaku untuk semua warga negara atau suatu golongan tertentu saja maupun yang beraku umum di sebagian wilayah negara. 2) Peraturan setempat yang hanya berlaku di suatu tempat atau daerah saja.

14 Bahwa jika benar bahwa dengan adanya Undang-Undang Nomor 2 tahun 2012 tentang Pengadaan Tanah Bagi Pembangunan Untuk Kepentingan Umum secara otomatis menghapuskan/ mencabut Undang-Undang Nomor 20 Tahun 1961 tentang Pencabutan Hak atas Tanah dan Benda Yang Ada Diatasnya, mengapa dalam pembahasan pembentukan RUU Pertanahan yang hingga sekarang masih menjadi perdebatan, masih dibahas mengenai keberlakuan Undang-Undang Nomor 20 tahun 1961 ini, yaitu dalam Kajian Naskah Akademik, dikatakan, “Dengan adanya Undang-Undang Nomor 2 Tahun 2012 tentang Pengadaan Tanah Bagi Pembangunan Untuk Kepentingan Umum (Undang-Undang Nomor 2 Tahun 2012) seakan kedudukan UU ini dikaburkan karena tidak disinggung di dalamnya. Undang-Undang Nomor 20 Tahun 1961 ini sebetulnya dimaksudkan untuk menjamin tersedianya tanah untuk kepentingan umum, untuk itu Presiden diberi kewenangan untuk mencabut hak atas tanah dengan memberikan ganti kerugian. Dalam hal ini presiden sebagai pemegang kekuasaan pemerintahan diberi kewenangan menggunakan instrumen hukum publik yaitu penetapan tertulis (beschikking) untuk mencabut hak demi kepentingan umum. Sepanjang RUU Pertanahan ini tidak mengatur tentang pencabutan hak atas tanah untuk kepentingan umum, maka Undang-Undang Nomor 20 Tahun 1961 tidak terpengaruh". Naskah Akademik RUU Pertanahan tahun 2017, halaman 27. Dengan demikian, dengan diberlakukannya Undang-Undang Nomor 2 Tahun 2012 tidak secara langsung/ otomatis menyebabkan dicabutnya/ tidak berlakunya Undang-Undang Nomor 20 Tahun 1961. 
berlaku belakangan yang mengatur pula hal tertentu tersebut, akan tetapi makna atau tujuannya berlainan atau berlawanan dengan undang-undang tersebut"... kita bisa melihat dalam ketentuan menimbang dalam Undang-Undang Nomor 2 Tahun 2012, bisa kita lihat bahwa tujuan dan hal tertentu yang diatur dalam kedua UU tersebut (UndangUndang Nomor 2 Tahun 2012 dan UndangUndang Nomor 20 Tahun 1961) tersebut sama, yaitu dilakukan dalam rangka untuk melaksanakan usaha-usaha pembangunan. Di dalam 2 peraturan perundangan tersebut yaitu Undang-Undang Nomor 20 Tahun 1961 dan Undang-Undang Nomor 2 tahun 2012, di dalam ketentuan menimbangnya terdapat tujuan yang sama, ketentuan menimbang dalam Undang-undang Nomor 20 Tahun 1961 tentang Pencabutan Hak-Hak atas Tanah dan Benda-benda yang ada diatasnya, yaitu “.... yaitu dalam rangka melaksanakan usahausaha pembangunan". Dalam ketentuan menimbang Undang-Undang Nomor 2 Tahun 2012 dinyatakan“.... dalam rangka mewujudkan masyarakat adil, makmur dan sejahtera berdasarkan Pancasila dan Undangundang Dasar Negara Republik Indonesia Tahun 1945, pemerintah perlu melaksanakan pembangunan."

Demikian pula, kedudukannya UndangUndang Nomor 2 Tahun 2012 dengan UndangUndang Nomor 20 Tahun 1961, dikatakan bahwa Undang-Undang Nomor 2 Tahun 2012 tentang Pengadaan Tanah Bagi Pembangunan Untuk Kepentingan Umum (UU No. 2 Tahun
2012) juga sebagai pelaksana UUPA. Namun delegasi pengaturannya untuk UndangUndang Nomor 20 Tahun 1961 lebih tegas yaitu perintah dari Pasal 18 UUPA, sementara UU No. 2 Tahun 2012 tidak mengacu kepada pasal tertentu dari UUPA. ${ }^{15}$ Dan juga dalam "ketentuan penutup" UU No. 2 tahun 2012 tidak terdapat pernyataan/ ketentuan yang menyatakan bahwa dengan adanya UU No. 2 Tahun 2012 untuk mencabut undang-undang/ peraturan sebelumnya (termasuk di dalamnya Undang-Undang Nomor 20 Tahun 1961). Sehingga dengan tidak adanya "ketentuan penutup" yang menyatakan bahwa bahwa UU No. 2 Tahun 2012 tentang Pengadaan Tanah Bagi Pembangunan Untuk Kepentingan Umum maka Undang-Undang 20 Tahun 1961 tentang Pencabutan Hak-Hak atas Tanah dan Benda-benda yang ada diatasnya tetap (dianggap) berlaku.

Dalam kenyataannya, mengenai keberlakuan Undang-Undang 20 Tahun 1961 tidak lagi dipergunakan, termasuk tidak dimasukkan di dalam cara penyelesaian sengketa/ konflik dalam pengadaan tanah yang terdapat dalam UU No. 2 Tahun 2012 secara tersirat adanya keengganan dari pemerintah/ institusi yang berkaitan dengan pelaksanaan pengadaan tanah dikarenakan adanya kekhawatiran muncul anggapan bahwa negara berlaku secara sewenangwenang, selain jika menggunakan metode penyelesaian sengketa/ konflik pengadaan tanah dilakukan dengan pencabutan hak maka akan sangat panjang prosedur/ mekanisme

15 Naskah Akademik RUU Pertanahan tahun 2017, halaman 27. Dan bahkan disampaikan dalam Naskah Akademik tersebut, jika UU No. 2 Tahun 2012 dikaitkan dengan RUU Pertanahan ini, sepanjang terkait pengadaan tanah untuk pembangunan kepentingan umum, cukup mengatur secara umum saja, sedangkan secara rinci mengacu kepada UU No.2 Tahun 2012. Sehingga walaupun lahirnya lebih dahulu daripada RUU Pertanahan ini, UU No.2 Tahun 2012 berkedudukan juga sebagai pelaksana RUU Pertanahan ini nantinya, terlepas dari substansi UU No.2 Tahun 2012 yang masih banyak perlu dipertanyakan. 
(karena dilakukan oleh Presiden) ${ }^{16}$, hal ini berbeda jika penyelesaian sengketa/ konflik yang muncul karena pengadaan tanah dilakukan dengan metode konsinyasi (penitipan ganti kerugian di Pengadilan Negeri) maka waktu penyelenggaraan untuk pelaksanaan pengadaan tanah relatif menjadi lebih pendek/ cepat. ${ }^{17}$

Berdasarkan dari uraian diatas, UndangUndang 20 Tahun 1961 tentang Pencabutan Hak-Hak atas Tanah dan Benda-benda yang ada diatasnya, diibaratkan dalam keadaaan antara "ada dan tiada", karena dalam UU No. 2 Tahun 2012 yang mengatur tentang Pengadaan Tanah Bagi Pembangunan Untuk Kepentingan Umum, dalam "ketentuan penutup" yang menyatakan bahwa dengan adanya UU No. 2 Tahun 2012 untuk mencabut UU/ peraturan sebelumnya (termasuk di dalamnya Undang-Undang Nomor 20 Tahun 1961).

\section{Kemungkinan digunakannya kembali Pencabutan Hak Atas Tanah sebagai tatacara memperoleh tanah bagi pembangunan untuk kepentingan umum}

Kebutuhan tanah yang demikian tinggi untuk pembangunan infrastruktur di satu sisi dan tugas negara untuk mewujudkan kemakmuran dan kesejahteraan rakyat di sisi lain. Maka, sangat dimungkinkan untuk dipergunakannya kembali mekanisme pencabutan hak atastanah sebagaicara "akhir" untuk penyelesaian jikalau terjadi sengketa/ konflik yang muncul dalam penyelenggaraan pengadaan tanah, sepanjang indikator dan prinsip pengadaan tanah dapat dipenuhi, yaitu bahwa pengadaan tanah yang dilakukan tersebut benar pembangunannya (akan) dipergunakan untuk kepentingan umum. Dan tidak ada penyimpangan terhadap prinsip pengadaan tanah yaitu prinsip kemanusiaan, demokratis dan adil.

Begitu pula dengan pendapat Boedi Harsono $^{18}$, yang menyatakan bahwa pencabutan hak tidak hanya dikenal di Indonesia saja, namun juga dikenal di negara-negara lain, misalnya di Malaysia, di Singapura, begitu pula di negara Jepang pun dikenal mekanisme pencabutan hak. Dalam Undang-Undang Pengadaan Tanah di Malaysia diatur dalam Land Aquisition Act 1960, yang mengatur bahwa baik negara federal, maupun negara bagian, pemerintah dan pejabat negara mempunyai kewenangan berdasarkan undang-undang untuk mengakuisisi tanah untuk kepentingan umum. ${ }^{19}$ Kapan pun pejabat yang berwenang akan bermaksud untuk melakukan pengadaan tanah harus menyatakan maksud tersebut dan dimuat dalam Berita Negara (Gezette). Dan pihak yang tanahnya dipergunakan untuk pengadaan tanah mendapatkan kompensasi

16 Pencabutan hak dimungkinkan, tetapi diikat dengan syarat-syarat, misalnya harus disertai pemberian ganti kerugian yang layak. Dan dengan mengingat prinsip penghormatan terhadap hak atas tanah,apabila tanah yang sudah dikuasai oleh pemegang hak secara sah, jika diperlukan untuk pembangunan harus didahului dengan musyawarah terlebih dahulu. Apabila musyawarah tidak mencapai kesepakatan, maka proyek tidak boleh dipaksakan dilaksanakan di lokasi tersebut.

17 Hasil Wawancara Bapak Dr. Yagus Suyadi., SH., M. Si, Kepala Bagian Perundang-undangan Biro Hukum dan Hubungan Masyarakat, 8 Agustus 2017, Pukul: 15. 15 WIB.

18 Boedi Harsono, Hukum Agraria Indonesia Sejarah Pembentukan Undang Undang Pokok Agraria, Isi Dan Pelaksanaannya, Jakarta: Penerbit Djambatan, 2008.

19 Anuar Alias and MD, University of Malaysia, Pasific Rim Property Research Journal, Vo. 12 No. 3, hlm. 326 
yang wajar. Yang menjadi persoalan kemudian adalah undang-undang tidak mendefinisikan apa yang dimaksud dengan kompensasi yang wajar, sehingga hal ini dalam praktik menimbulkan perbedaan penafsiran. ${ }^{20}$

Pengaturan tentang pengadaan tanah di Malaysia dikenal pula pencabutan hak atas tanah, yang diatur dalam Kanun tanah negara 1965 (Akta 560) berdasarkan Pasal 52 ayat (2) dan Pasal 70, yang berhak mengambil tanah adalah pihak berkuasa negeri. Yang dimaksudkan dengan pihak berkuasa negeri adalah Raja, atau Gubernur, atau Pemerintah. Dalam proses pengambilan tanah, yang dilakukan oleh raja, atau gubernur atau pemerintah, terlebih dahulu diajukan permohonan kepada Mahkamah Tinggi Malaysia. Sebelum Mahkamah Tinggi memutuskan, pemohon terlebih dahulu harus berunding mengenai nilai dan harga tanah yang akan dibayar dan harus sesuai dengan harga pasar atau memberikan tanah pengganti kepada pemiliknya. Setelah pihakpihak setuju barulah Mahkamah memutuskan tentang ganti rugi yang diberikan kepada pemilik tanah. ${ }^{21}$

Pengaturan tentang pengadaan tanah di Singapura diatur dalam Land Acquisition Act 41 of 1966, yang menyatakan bahwa apabila presiden menyatakan bahwa suatu tanah diperlukan untuk kepentingan publik, maka pernyataan tersebut harus diumumkan di Berita Negara (Gezette), dan pejabat yang berwenang (Collector) harus menyampaikan pen- gumuman tersebut pada tempat-tempat yang dianggap perlu. ${ }^{22}$ Pejabat yang berwenang mengurus mengenai pengadaan tanah disebut Collector. Keputusan collector mengenai kompensasi adalah final. Yang artinya jika collector membuat keputusan mengenai kompensasi, maka dia dapat mengambilalih tanah tersebut setelah memberitahukan secara tertulis tindakan tersebut kepada pihak-pihak yang terkena. Dalam hal atas perintah menteri, maka collector akan mengambilalih tanah dimaksud, walaupun kompensasi belum ditetapkan dengan terlebih dahulu memberitahukan maksud itu 7 (tujuh) hari sebelumnya. Setelah pengambilalihan tanah tersebut, maka collector memberitahukan kepada land register untuk mencatat dalam register bahwa tanah tersebut adalah di bawah kekuasaan negara. ${ }^{23}$

Jepang pun mengenal pencabutan hak atas tanah dalam proses pengadaan tanah/ penyediaan tanah untuk pembangunan. Dalam peraturan perundang-undangan di Jepang, wewenang untuk melaksanakan pengadaan tanah baik rencana maupun persetujuannya terdapat pada Ministry of Land, Infrastructure and Transport. Pemerintah atau pihak yang membutuhkan tanah, baru akan memulai pengadaan tanah secara paksa apabila lebih dari $80 \%$ setuju atau setelah 3 tahun dari pengumuman pengadaan tanah yang mana yang terpenuhi terlebih dahulu. Ketentuan ini haruslah diumumkan kepada semua pihak yang terkait dengan pengadaan tanah. ${ }^{24}$

\footnotetext{
20 Anuar Alias and MD, University of Malaysia, Pasific Rim Property Research Journal, Vo. 12 No. 3, hlm. 326.

21 Bernard Limbong, Pengadaan Tanah Untuk Pembangunan-Regulasi Kompensasi Penegakan Hukum, Jakarta: Margaretha Pustaka, 2011, hlm. 288.

22 Gunanegara, Hukum Administrasi Negara, Jual Beli dan Pembebasan Tanah, Jakarta: PT. Tatanusa, 2016 , hlm. 64.

23 Ibid, hlm. 65.

24 Gunanegara, Hukum Administrasi Negara, Jual Beli dan Pembebasan Tanah, Jakarta: PT. Tatanusa, 2016, hlm. 67 dalam Rofi Wahanisa, Politik Hukum Penyelesaian Sengketa/ Konflik Pengadaan Tanah Bagi Pembangunan Untuk Kepentingan Umum Pasca Reformasi 1998-2016, Disertasi Undip, 2019, hlm. 471
} 
Oleh karena itu di Indonesia, dengan menganut prinsip negara hukum ${ }^{25}$, dan sekaligus negara kesejahteraan, dengan pembatasan dalam hak menguasai negara, jika dikaitkan dengan kegiatan pengambilalihan tanah (pengadaan tanah) untuk kepentingan umum, maka sebagaimana diatur dalam Undang-Undang Nomor 20 Tahun 1961, dikatakan bahwa pencabutan hak dimungkinkan, namun harus diikat dengan syarat-syarat, harus disertai dengan pemberian ganti kerugian yang layak. Hal ini tentu saja tetap dengan prinsip penghormatan terhadap hak asasi manusia terhadap kepemilikan tanah oleh pemeganh hak atas tanah. Namun, jika terdapat proyek/ kegiatan untuk kepentingan umum, dan jika diperlukan untuk pembangunan harus didahului dengan musyawarah terlebih dahulu. Apabila musyawarah tidak mencapai kesepakatan, maka proyek tidak boleh dipaksakan dilaksanakan di lokasi tersebut.

$\mathrm{Hal}$ ini karena kewenangan untuk memperoleh tanah demi pelaksanaan pembangunan untuk kepentingan umum sesungguhnya bersifat universal. Kewenangan negara juga dilindungi secara konsitusi dengan adanya hak menguasai negara. Begitu pula dalam Pasal 33 ayat 3, dimana bumi, air, dan kekayaan alam dipergunakan untuk kesejahteraan rakyat. Dengan berpegang pada prinsip-prinsip yang mendasari pengadaan tanah oleh pemerintah tersebut mengacu kepada pribahasa:

"salus papuli est suprema lax (kesejahteraan rakyat adalah hukum yang tertinggi), necessitas publica major est quam privata (kepentingan umum lebih besar daripada kepentingan pribadi), princeps et respublica ex justa causa possunt rem meam auferre/ the prince and the commonwealth, for a just cause, can take away my property (penguasa dan negara, dengan alasan yang layak/memadai, dapat mengambil alih kepentingan pribadi), the law imposeth it on every subject that he prefers the urgent service of his Prince and Country, before the safety of his life (hukum mewajibkan seseorang untuk mendahulukan kepentingan negara daripada keselamatan pribadinya)". ${ }^{26}$

Hal ini senada dengan pendapat dari Miriam Budiarjo dalam bukunya dasardasar Ilmu Politik menuliskan bahwa negara merupakan integrasi dari kekuasaan politik, negara adalah organisasi pokok dari kekuasaan politik. Negara adalah alat (agency) dari masyarakat dan menertibkan gejala-gejala kekuasaan terjadi. ${ }^{27}$ Sehingga berkaitan dengan tanah, negara selaku organisasi kekuasaan seluruh rakyat, bertindak dalam kedudukannya sebagai kuasa dan petugas Bangsa Indonesia. Dalam melaksanakan tugas tersebut ia merupakan organisasi kekuasaan rakyat yang tertinggi.

25 Yang dimaksudkan dengan ajaran negara berdasarkan atas hukum (de rechts staat dan the rule of law) mengandung pengertian bahwa hukum adalah supreme dan kewajiban bagi setiap penyelenggara negara atau pemerintah untuk tunduk pada hukum (subject the law). Tidak ada kekuasaan diatas hukum (above to the law), dalam buku Bagir Manan, Lembaga Kepresidenan, Jakarta: FH UII Press, 2003, hlm 11, yaitu yang berarti bahwa Atas dasar pernyataan diatas maka tidak boleh ada kekuasaan yang sewenang-wenang (arbitrary power) atau penyalahgunaan kekuasaan (misuse of power) baik pada negara berbentuk kerajaan maupun republik.

26 Om Prakash Anggarwala, Compulsory of Land In India Commentary On The Acquisition Of Land Act, 1 of 1894, (New Delhi India: The University Book Agency, 1993), hal. 16-17 dalam Makalah irine Eka Sihombing, "Menghidupan Pencabutan Hak Atas Tanah Sebagai Salah Satu Cara Perolehan Tanah Oleh Pemerintah", Seminar FH Trisakti tentang Problematika Pertanahan, tanggal 27 Oktober 2017.

27 Miriam Budiarjo, Dasar-dasar Ilmu Politik, Jakarta: PT. Gramedia 
Oleh karena menjadi tujuan dan tugas negara untuk mewujudkan keadilan dan kesejahteraan, karena sejatinya "mahkota" dari hukum adalah keadilan sebagaimana pendapat Gustav Radburch yang menyatakan bahwa 3 nilai dasar dari hukum yaitu keadilan, kemaanfaatan dan kepastian. Hukum sebagai pengemban nilai keadilan, menjadi ukuran adil tidaknya sebuah tata hukum. Keadilan memiliki sifat normatif sekaligus konstitutif bagi hukum. normatif karena berfungsi sebagai prasyarat transendental yang mendasari tiap hukum positif yang bermartabat. la menjadi landasan moral hukum sekaligus sebagai tolok ukur sistem hukum positif. Karena kepada keadilan-lah, hukum positif berpangkal. Sedangkan konstitutif, karena keadilan harus menjadi unsur mutlak bagi hukum sebagai hukum. Tanpa keadilan, sebuah aturan tidak pantas menjadi hukum. ${ }^{28}$

Keadilan juga dimaknai oleh John Rawls ${ }^{29}$ dalam Theory of Justice menyatakan bahwa keadilan tidak membiarkan pengorbanan yang dipaksakan pada segelintir orang diperberat oleh sebagian besar keuntungan yang dinikmati banyak orang. Berdasarkan hal tersebut, keadilan persepsi Rawls harus dapat diterima dan dirasakan oleh semua orang tanpa kecuali.

Hal diatas sejalan dengan pendapat Jean Jacques Rosseou menyatakan bahwa pada saat individu yang satu bergabung dengan individu yang lain yang disebut sebagai masyarakat, yang kemudian bergabungnya masyarakat menjadi satu bangsa, dan pada saat tersebut secara konseptual mereka telah menyerahkan sebagian hak individunya kepada negara untuk diatur guna memberikan harmoni antara mereka yang disebut dengan social order. ${ }^{30}$

Bagi Jeremy Bentham ${ }^{31}$ keadilan juga dimaknai sebagai kebahagiaan terbesar oleh sebagian masyarakat, sehingga jika dianggap bahwa dengan dilakukan pencabutan hak atas tanah akan lebih banyak membawa kemanfaatan, kebahagiaan dan keadilan bagi sebagian besar masyarakat. Berdasarkan apa yang disampaikan Bentham tersebut seharusnya tidak perlu adanya ketakutan dari para negara/ pemerintah termasuk kepada institusi penyelenggara pengadaan tanah dan pelaksana pengadaan tanah untuk melakukan pencabutan hak atas jika tanah hak seseorang akan dipergunakan untuk kepentingan umum, sepanjang benar bahwa penggunaan tanah hak (dari pemegang hak atas tanah/individu) tersebut dipergunakan untuk pembangunan fasilitas untuk kepentingan umum. Hal-hal yang terkait dengan tata cara pencabutan hak atas tanah telah jelas diatur dalam UndangUndang 20 Tahun 1961 tentang Pencabutan Hak-Hak atas Tanah dan Benda-benda yang ada diatasnya. Karena cara pencabutan hak atas tanah sejatinya adalah cara untuk memperoleh hak atas tanah yang sah dan diatur oleh Undang-undang.

28 Bernard L. Tanya, dkk, teori Hukum Strategi Tertib Manusia Lintas Ruang dan Generasi, Yogyakarta: Genta Publishing, 2010, hlm. 130.

29 Rawls, J. , Theory of Justice (Teori Keadilan: Dasar-dasar Filsafat Politik Untuk Mewujudkan Kesejahteraan Sosial dalam Negara), Penerjemah: Fauzan dan Prasetyo, Yogyakarta: Pustaka Pelajar, 2011.

30 Gunanegara, Rakyat Dan Negara Dalam Pengadaan Tanah Untuk Pembangunan, Jakarta: PT. Tatanusa, 2008, hlm. 12.

31 Jeremy Bentham, An Introduction to the Principles of Morals and Legislation, Kitchener, Batoche Books, 2000, hlm. 14 . 
Akan tetapi dalam UU No. 2 Tahun 2012 yang mengatur tentang Pengadaan Tanah Bagi Pembangunan Untuk Kepentingan Umum, dalam pengaturannya yang terkait dengan penyelesaian sengketa/ konflik pengadaan tanah, jalan akhir penyelesaian sengketa/ konflik tidak menggunakan pencabutan hak yang sah diatur oleh Undang-undang (UU No. 20 Tahun 1961) tetapi menggunakan cara konsinyasi (penitipan uang ganti kerugian di Pengadilan Negeri). Sedangkan Menurut Maria Soemardjono, cara akhir penyelesaian sengketa/ konflik dalam pengadaan tanah melalui cara konsinyasi ini tidaklah tepat. Maria Soemardjono menyebutkan bahwa secara konsep, penggunaan lembaga penitipan melalui analogi dengan Pasal 1404 Kitab Undang-Undang Hukum Perdata adalah keliru. Pasal Kitab Undang-Undang Hukum Perdata mengatur tentang lembaga penawaran pembayaran diikuti dengan penitipan pada Pengadilan Negeri dilandasi pada hubungan yang bersifat keperdataan antara para pihak yang berawal dari adanya hubungan utang piutang. Pengadaan tanah adalah perbuatan hukum pemerintah untuk memperoleh tanah yang termasuk dalam ranah hukum administrasi. Untuk memperoleh tanah dari pemegang hak atas tanah, pemerintah memberikan ganti kerugian. Jelaslah bahwa hubungan antara pemerintah dengan pemegang hak atas tanah bukanlah hubungan utang piutang yang bersifat keperdataan. Ketika pemegang hak atas tanah menolak untuk menerima ganti kerugian yang ditawarkan oleh instansi pemerintah yang memerlukan tanah, maka tindakan untuk menitipkan uang ganti kerugian di Pengadilan Negeri merupakan tindakan yang bersifat sepihak, bahwa dengan telah dititipkannya uang ganti kerugian itu dianggap bahwa seolah-olah telah terjadi kesepakatan untuk menerima ganti kerugian tersebut dan bahwa tanggung jawab untuk membayar ganti kerugian dipandang telah dilaksanakan. ${ }^{32}$

Cara konsinyasi sangat bertentangan dengan asas perolehan tanah yang menyatakan bahwa untuk memperoleh tanah yang diperlukan tidak dibenarkan adanya paksaan dalam bentuk apapun dan oleh pihak siapapun kepada pemegang haknya, untuk menyerahkan tanah kepunyaannya dan atau menerima ganti kerugian yang tidak disetujuinya, termasuk juga penggunaan lembaga "penawaran pembayaran yang diikuti dengan konsinyasi pada Pengadilan Negeri" seperti yang diatur dalam Pasal 1404 Kitab Undang-Undang Hukum Perdata. ${ }^{33}$

Maka sangat dimungkinkan dipergunakan kembali pencabutan hak atas tanah sebagai mekanisme untuk memperoleh tanah bagi pemerintah untuk pembangunan, dengan pembatasan: ${ }^{34}$

1) Bahwa pencabutan hak atas tanah boleh dilaksanakan apabila musyarawarah tentang pelepasan hak dan ganti kerugian tidak mencapai kesepakatan, sementara itu kegiatan yang akan dilaksanakan adalah kegiatan dalam rangka kepentingan umum 
yang lokasinya tidak dapat dipindahkan ke tempat lain.

2) Pencabutan hak merupakan tindakan yang sangat penting, karena berakibat mengurangi hak seseorang maka yang memutuskannya adalah pejabat eksekutif yang tertinggi, yaitu Presiden.

3) Panitia penaksir harus melakukan penaksiran yang objektif, dengan memperhatikan harga penjualan tanah/ bangunan/tanaman dalam tahun berjalan. Karena selama ini yang kerapkali menjadi permasalahan hingga timbul sengketa/ konflik terkait dengan pengadaan tanah adalah yang berkaitan dengan bentuk dan besaran ganti kerugian. Soal bentuk, seringkali hanya berupa nilai nominal (tunai/ uang) yang diberikan sedangkan dalam peraturan perundangan terkait dengan pengadaan tanah, dimungkinkan bentuk ganti rugi dengan penggantian tanah, pemukiman kembali, maupun keikutsertaan saham. Soal besaran ganti rugi, yang seringkali tidak sesuai dengan harapan dari pemilik tanah. Hal ini hendaknya juga disadari oleh pemilik tanah, bahwa subyek yang membutuhkan tanah dalam pengadaan tanah adalah negara (dipergunakan untuk kepentingan umum) pemberian ganti kerugian pun berdasarkan Anggaran Pendapatan dan Belanja Negara (APBN) atau Anggaran Pendapatan dan Belanja Daerah (APBD) yang nilai nominalnya terbatas.

4) Pembayaran ganti-rugi kepada orangorang yang hak atas tanahnya dicabut, oleh yang berkepentingan harus dilakukan secara tunai dan dibayarkan langsung kepada yang berhak.

5) Pemegang hak atas tanah diberikan kemungkinan untuk mengajukan banding ke Pengadilan Tinggi, apabila tidak bersedia dengan ganti kerugian yang ditawarkan.

6) Jalan akhir penyelesaian jika terjadi sengketa/ konflik tidak dilakukan dengan cara konsinyasi (penitipan ganti kerugian di Pengadilan Negeri)

Kemudian, yang menjadi sangat penting untuk diingat adalah dalam melaksanakan penyelenggaraan pengadaan tanah bagi pembangunan untuk kepentingan umum adalah dengan menjunjung prinsipprinsip pengadaan tanah, yaitu prinsip kemanusiaan, demokrasi dan adil. Dan dalam penyelenggaraan kegiatan pengadaan tanah di masa mendatang lebih mengakomodasi penghormatan dan perlindungan hak asasi manusia, keberlanjutan kapasitas produksi masyarakat, dan pemberdayaan masyarakat, karena selama ini peraturan perundangan belum maksimal menjangkau hal ini. ${ }^{35}$

\section{Penutup}

Berdasarkan uraian tersebut diatas, dengan disahkannya Undang-Undang Nomor 2 Tahun 2012 tentang Pengadaan Tanah Bagi Pembangunan Untuk Kepentingan Umum ini, tetap ada dan berlaku. Namun dalam UndangUndang Nomor 2 Tahun 2012 yang mengatur tentang Pengadaan Tanah Bagi Pembangunan Untuk Kepentingan Umum tidak dipergunakan pencabutan hak atas tanah dan benda-benda

35 Maria S.W. Soemardjono. Tanah dalam Perspektif Hak Ekonomi Sosial dan Budaya. Jakarta: Penerbit Buku Kompas, 2008, hlm. 271. 
yang ada diatasnya sebagai cara akhir untuk penyelesaian sengketa/ konflik yang muncul dalam kegiatan pengadaan tanah, namun digantikan dengan cara konsinyasi.

Namun secara konseptual cara ini tidak tepat, karena pengadaan tanah adalah perbuatan hukum pemerintah untuk memperoleh tanah yang termasuk dalam ranah hukum administrasi. Sehingga untuk memperoleh tanah dari pemegang hak, pemerintah memberikan ganti kerugian. Hubungan antara pemerintah dengan pemegang hak atas tanah bukanlah hubungan utang piutang yang bersifat keperdataan. Oleh karena itu ketika pemegang hak atas tanah menolak untuk menerima ganti kerugian yang ditawarkan oleh instansi pemerintah yang memerlukan tanah, maka tindakan untuk menitipkan uang ganti kerugian di Pengadilan Negeri merupakan tindakan yang bersifat sepihak, bahwa dengan telah dititipkannya uang ganti kerugian itu dianggap bahwa seolah-olah telah terjadi kesepakatan untuk menerima ganti kerugian.

Dengan demikian, sangat dimungkinkan untuk dipergunakannya kembali cara pencabutan hak atas tanah, jika tidak dicapai kesepakatan antara para pihak (instansi/ pemerintah/ negara) yang memerlukan tanah dengan pemegang hak atas tanah. Karena dengan masih berlakunya (belum dicabut) Undang-Undang 20 Tahun 1961 tentang Pencabutan Hak-Hak atas Tanah dan Bendabenda yang ada diatasnya, maka ketentuan ini masih sah berlaku dan cara pencabutan hak merupakan cara yang sah dan tidak bertentangan dengan hukum.

\section{Daftar Pustaka}

\section{Buku}

Abdurahman, Setengah abad Pengaturan Tentang "Pengambilan Tanah Rakyat dari Pencabutan Hak sampai kepada Pembebasan Tanah Dalam Pengadaan Tanah bagi pembangunan Untuk Kepentingan Umum dalam Perkembangan Hukum di Indonesia, dalam Rangka 70 Tahun Prof. Dr. Mieke Komar, SH., M.CL, (Bandung: PT. Remaja Rosdakarya)

Bongdan, Robert dan Teven J. Taylor. Kualitatif, Dasar-dasar Penelitian, Terjemahan A. Khozin Afandi, (Surabaya: Usaha Nasional, 1993)

Budiarjo, Miriam Dasar-dasar IImu Politik, (Jakarta: PT. Gramedia)

Sitorus, Oloan, Dayat Limbong. Pengadaan Tanah Untuk Kepentintingan Umum, (Yogyakarta: Penerbit Mitra Kebijakan Tanah Indonesia, 2004)

Gunanegara. Rakyat Dan Negara Dalam Pengadaan Tanah Untuk Pembangunan, (Jakarta: PT. Tatanusa, 2008)

Gunanegara. Hukum Administrasi Negara, Jual Beli dan Pembebasan Tanah, (Jakarta: PT. Tatanusa, 2016)

Hidayat, Arief. Kebebasan Berserikat Di Indonesia (Suatu Analisis Pengaruh Perubahan Sistem Politik Terhadap Penafsiran Hukum), (Semarang: Badan Penerbit Universitas Diponegoro, 2006)

Limbong. Bernard Pengadaan Tanah Untuk Pembangunan-Regulasi Kompensasi Penegakan Hukum, (Jakarta: Margaretha Pustaka, 2011)

Mattew B. Miles, L. dan A. Michael Huberman. Analisis Data Kualitatif, (Jakarta: UI Press ,1992)

Parlindungan, AP. Pencabutan dan Pembebasan Hak Atas Tanah Suatu Studi Perbandingan, Cet. I, Bandung: Mandar maju, 1993)

Rawls, J. Theory of Justice (Teori Keadilan: Dasardasar Filsafat Politik Untuk Mewujudkan Kesejahteraan Sosial dalam Negara), Penerjemah: Fauzan dan Prasetyo, (Yogyakarta: Pustaka Pelajar, 2011)

Soehino. Hukum Tata Negara Tekhnik (Setelah Dilakukan Perubahan Pertama dan Kedua Undang-undang Dasar Negara Republik Indonesia Tahun 1945), Edisi Pertama, 
(Yogyakarta: BPFE Fakultas Ekonomi UGM, 2006)

Soekanto, Soerjono dan Sri Mamudji. Penelitian Hukum Normatif: Suatu Tinjauan Singkat, Ed.1, Cet.3, Jakarta: Rajawali, 1990)

Sumardjono, Maria S.W. Tanah Dalam Perspektif Hak Ekonomi Sosial Dan Budaya, (Jakarta: Penerbit Buku Kompas, 2009)

Tanya, Bernard L. Dkk. Teori Hukum Strategi Tertib Manusia Lintas Ruang dan Generasi, (Yogyakarta: Genta Publishing, 2010)

\section{Makalah/Jurnal/ Artikel/Hasil Seminar}

Alias, Anuar and MD, University of Malaysia, Pasific Rim Property Research Journal, Vo. 12 No. 3

Sihombing, Irine Eka "Menghidupan Pencabutan Hak Atas Tanah Sebagai Salah Satu Cara Perolehan Tanah Oleh Pemerintah", Seminar FH Trisakti tentang Problematika Pertanahan, tanggal 27 Oktober 2017

Wahanisa, Rofi. Politik Hukum Penyelesaian Sengketa/ Konflik Pengadaan Tanah Bagi Pembangunan Untuk Kepentingan Umum Pasca Reformasi 1998-2016, Disertasi UNDIP, 2019. 